\section{The lack of association between catechol- 0 -methyl-transferase Val108/158Met polymorphism and smoking in schizophrenia and alcohol dependence}

\section{To the Editors}

Patients with schizophrenia and alcohol dependence are often smokers. There are inconsistencies across the literature on the relationship between the functional catechol-O-methyl-transferase (COMT) Val108/158Met polymorphism and smoking and/or nicotine dependence (Redden et al., 2005; Tammimaki and Mannisto, 2010).

The study elucidated the association between the COMT Val108/158Met polymorphism and smoking in 828 ethnically homogeneous non-related Caucasian patients with schizophrenia $(40.3 \pm 12.6$ years old $), 616$ patients with alcohol dependence $(49.7 \pm 10.2$ years old), diagnosed with the Structured Clinical Interview for DSM-IV, and in 1058 healthy control subjects $(40.5 \pm 15.3$ years old $)$. The COMT Val108/158Met polymorphism was genotyped using a Taqman-based allele-specific polymerase chain reaction assay (Applied Biosystems, Foster City, CA, USA).

COMT genotypes in the studied groups were in HardyWeinberg equilibrium. The present smoking status differed significantly $\left(\chi^{2}=327.71 ; P<0.001\right)$ between the studied groups, since male patients with schizophrenia smoked more frequently, while healthy control women smoked less frequently than other subjects. The stepwise logistic regression (odds ratio $(\mathrm{OR})=1.56$, $95 \%$ confidence interval $(\mathrm{CI})=1.10-2.23, P=0.014)$ and the $\chi^{2}$ test (Table 1 ) revealed that the COMT Val/Val genotype was significantly associated with smoking in healthy male subjects, since carriers of one $\left(\chi^{2}=5.686 ; P=0.017\right)$ or two $\left(\chi^{2}=9.783 ; P=0.008\right)$ Val alleles were more frequently current smokers.

The significant association between smoking, age and gender, with no interaction between smoking and COMT Val108/158Met variants in patients with schizophrenia and alcohol dependence, might be explained by the different effects of nicotine on social and interpersonal factors in psychiatric versus healthy subjects, or by the different interactions between dopamine activity and nicotine in the regions involved in the regulation of the reward pathways in healthy opposed to subjects with schizophrenia and alcohol dependence. Although the hypothesis of the study was that COMT Val108/158Met genotypes would be significantly associated with smoking in schizophrenia and alcohol dependence, our study, with a sufficiently large sample size $(N=2502)$ and power (higher than 0.800$)$, with subjects matched for the first time the lack of a significant association between smoking and the COMT Val108/158Met polymorphism in schizophrenia, and confirmed no association between smoking and the COMT Val108/158Met polymorphism in alcoholism (Foroud et al., 2007). In line with previous results obtained in smaller groups
Table 1

COMT Val108/158Met genotype counts and frequencies in male and female control subjects, and patients with schizophrenia or alcohol dependence, further subdivided according to the smoking status into smokers and non-smokers.

\begin{tabular}{|c|c|c|c|c|c|c|}
\hline & \multicolumn{6}{|c|}{ COMT Val ${ }^{108 / 158}$ Met genotype } \\
\hline & \multicolumn{3}{|c|}{ Male subjects } & \multicolumn{3}{|c|}{ Female subjects } \\
\hline & $\begin{array}{l}\text { Met/Met } \\
N(\%)\end{array}$ & $\begin{array}{l}\mathrm{Val} / \mathrm{Met} \\
N(\%)\end{array}$ & $\begin{array}{l}\mathrm{Val} / \mathrm{Val} \\
N(\%)\end{array}$ & $\begin{array}{l}\text { Met/Met } \\
N(\%)\end{array}$ & $\begin{array}{l}\mathrm{Val} / \mathrm{Met} \\
N(\%)\end{array}$ & $\begin{array}{l}\mathrm{Val} / \mathrm{Val} \\
N(\%)\end{array}$ \\
\hline $\begin{array}{l}\text { Healthy control } \\
\text { smokers }\end{array}$ & $\begin{array}{l}56 \\
(25.7)\end{array}$ & $\begin{array}{l}93 \\
(42.7)\end{array}$ & $\begin{array}{c}69^{a} \\
(31.6)\end{array}$ & $\begin{array}{c}15 \\
(22.4)\end{array}$ & $\begin{array}{l}39 \\
(55.2)\end{array}$ & $\begin{array}{c}15 \\
(22.4)\end{array}$ \\
\hline $\begin{array}{l}\text { Healthy control } \\
\text { non-smokers }\end{array}$ & $\begin{array}{l}108 \\
(22.2)\end{array}$ & $\begin{array}{l}267 \\
(54.9)\end{array}$ & $\begin{array}{l}111 \\
(22.9)\end{array}$ & $\begin{array}{l}78 \\
(28.6)\end{array}$ & $\begin{array}{r}134 \\
(45)\end{array}$ & $\begin{array}{l}73 \\
(26.4)\end{array}$ \\
\hline $\begin{array}{l}\text { Smokers with } \\
\text { schizophrenia }\end{array}$ & $\begin{array}{l}104 \\
(27.2)\end{array}$ & $\begin{array}{l}185 \\
(48.4)\end{array}$ & $\begin{array}{c}93 \\
(24.4)\end{array}$ & $\begin{array}{c}29 \\
(23.6)\end{array}$ & $\begin{array}{l}58 \\
(47.1)\end{array}$ & $\begin{array}{c}36 \\
(29.3)\end{array}$ \\
\hline $\begin{array}{l}\text { Non-smokers } \\
\text { with } \\
\text { schizophrenia }\end{array}$ & $\begin{array}{c}47 \\
(26.7)\end{array}$ & $\begin{array}{l}87 \\
(49.4)\end{array}$ & $\begin{array}{l}42 \\
(23.9)\end{array}$ & $\begin{array}{l}31 \\
(21.1)\end{array}$ & $\begin{array}{c}68 \\
(46.3)\end{array}$ & $\begin{array}{c}48 \\
(32.6)\end{array}$ \\
\hline $\begin{array}{l}\text { Smokers with } \\
\text { alcoholism }\end{array}$ & $\begin{array}{l}75 \\
(24.9)\end{array}$ & $\begin{array}{l}154 \\
(51.2)\end{array}$ & $\begin{array}{l}72 \\
(23.9)\end{array}$ & $\begin{array}{l}23 \\
(33.8)\end{array}$ & $\begin{array}{l}30 \\
(44.1)\end{array}$ & $\begin{array}{l}15 \\
(22.1)\end{array}$ \\
\hline $\begin{array}{l}\text { Non-smokers } \\
\text { with } \\
\text { alcoholism }\end{array}$ & $\begin{array}{l}52 \\
(27.1)\end{array}$ & $\begin{array}{l}103 \\
(53.6)\end{array}$ & $\begin{array}{l}37 \\
(19.3)\end{array}$ & $\begin{array}{l}14 \\
(25.4)\end{array}$ & $\begin{array}{l}27 \\
(49.2)\end{array}$ & $\begin{array}{c}14 \\
(25.4)\end{array}$ \\
\hline
\end{tabular}

COMT: catechol-O-methyl transferase; Met: methonine; Val: valine; $N$ : genotype count.

${ }^{\mathrm{a}} P=0.008$ vs. healthy male non-smokers $\left(\chi^{2}\right.$ test $)$.

(Nedic et al., 2010), the COMT Val108/158Met polymorphism was significantly associated with smoking in healthy male subjects, due to the over-representation of the Val/Val genotype in healthy male current smokers.

\section{References}

Foroud, T, Wetherill, L.F, Dick, D.M., Hesselbrock, V., Nurnberger Jr., J.I., Kramer, J., Tischfield, J., Schuckit, M., Bierut, L.J., Xuei, X., Edenberg, H.J., 2007. Lack of association of alcohol dependence and habitual smoking with catechol-Omethyltransferase. Alcoholism: Clinical and Experimental Research 31, 1773-1779.

Nedic, G., Nikolac, M., Borovecki, F., Hajnsek, S., Muck-Seler, D., Pivac, N., 2010. Association study of a functional catechol-o-methyltransferase polymorphism and smoking in healthy Caucasian subjects. Neuroscience Letters 473, 216-219.

Redden, D.T., Shields, P.G., Epstein, L., Wileyto, E.P., Zakharkin, S.O., Allison, D.B., Lerman, C., 2005. Catechol-O-methyl-transferase functional polymorphism and nicotine dependence: an evaluation of nonreplicated results. Cancer Epidemiology, Biomarkers \& Prevention 14, 1384-1389.

Tammimaki, A.E., Mannisto, P.T., 2010. Are genetic variants of COMT associated with addiction? Pharmacogenetics and Genomics 20, 717-741. 
Matea Nikolac, Gordana Nedic, Maja Mustapic, Dorotea Muck-Seler, Nela Pivac* Division of Molecular Medicine, Rudjer Boskovic Institute, Zagreb, Croatia E-mail address: npivac@irb.hr (N. Pivac)

Marina Sagud, Alma Mihaljevic Peles, Miro Jakovljevic University of Zagreb School of Medicine; University Hospital Center Zagreb, Zagreb, Croatia

Korona Nenadic Sviglin Center for Alcoholism and Other Addictions, Clinics for Psychiatry Vrapce, Zagreb, Croatia

Suzana Uzun, Oliver Kozumplik Department of General Psychiatry, Clinics for Psychiatry Vrapce, Zagreb, Croatia

Bjanka Vuskan Cusa University Hospital Center Zagreb, Department of Psychiatry, Zagreb, Croatia
Maja Zivkovic Neuropychiatric Hospital "Dr Ivan Barbot" Popovaca, Division for Acute Psychiatry, Popovaca, Croatia

Mladen Pavlovic Institute for Medical Research and Occupational Health, Zagreb, Croatia

Fran Borovecki

Department of Neurology, University Hospital Center Zagreb; Department for Functional Genomics, Center for Translational and Clinical Research, University of Zagreb School of Medicine, Zagreb,

Croatia

Received 16 May 2012

* Corresponding author. Tel.: +3851 4571207; fax: +38514561010 